\title{
Modular Distance Learning in the New Normal Education Amidst Covid-19
}

\author{
Geraldine D. Anzaldo
}

Talisay Elementary School, Talisay Calatagan, Batangas, Philippines.

Corresponding author details: Geraldine D. Anzaldo; geraldine.anzaldo@deped.gov.ph

\begin{abstract}
Education in the new normal is a challenging task in the Philippines in an attempt to push through education amidst the deadly pandemic caused by covid-19. The Department of Education (DepEd) and Commission on Higher Education (CHED) adopted and implemented the flexible model of blended learning despite many oppositions because of the risk to open classes because of the virus. The different learning modalities are the following: Modular (Printed), Modular (Digitized), Online, Educational TV, Radio-Based Instruction, Home Schooling and Blended Learning. For the cities where modern living is adapted and students and learners have the privilege of having internet connection at home, Online learning is implemented especially for the high schools and colleges but for those living in rural areas or provinces where internet connection is only available for only few, Modular Distance Learning is implemented. Modular Distance Learning is the use of Modules made by teachers with different tasks and learning activities based from the essential learning competencies.
\end{abstract}

Keyword: modular distance learning; new normal education; covid-19

\section{INTRODUCTION}

The new normal education along with the different modalities faced different disapprovals at first because of the risk but with the effort of education sectors in the Philippines it is done systematically for the goal of continuing education despite the pandemic.

There are different safety measures being implemented by the IATF or the Inter-Agency Task Force in order to prevent and mitigate the spread of Covid-19 while the teaching and learning process continues in the country to protect the teachers, parents and students' health and welfare. Some of the safety protocols includes: proper sanitation of the schools where modular learning is implemented by providing alcohol stands in every classroom for the parents' use, sanitizing footbath mats in every room's doorsteps, wearing face mask and face shield is a must for the teachers and parents and social distancing is strictly executed. For the online learning and other modalities where parents and their children stay at home as well as the teachers, they are prescribed to do proper hand washing and regular sanitizing of their homes.

\section{WHAT IS COVID 19?}

According to WHO, Coronavirus disease (COVID-19) is an infectious disease caused by a newly discovered coronavirus. Most people infected with the COVID-19 virus will experience mild to moderate respiratory illness and recover without requiring special treatment. Older people, and those with underlying medical problems like cardiovascular disease, diabetes, chronic respiratory disease, and cancer are more likely to develop serious illness.

The best way to prevent and slow down transmission is to be well informed about the COVID-19 virus, the disease it causes and how it spreads.
Protect yourself and others from infection by washing your hands or using an alcohol-based rub frequently and not touching your face.

The COVID-19 virus spreads primarily through droplets of saliva or discharge from the nose when an infected person coughs or sneezes, so it's important that you also practice respiratory etiquette (for example, by coughing into a flexed elbow).

\section{PREVENTION FROM COVID-19}

WHO cited the following to prevent infection and to slow transmission of COVID-19:

- Wash your hands regularly with soap and water, or clean them with alcohol-based hand rub.

- Maintain at least 1-meter distance between you and people coughing or sneezing.

- Avoid touching your face.

- Cover your mouth and nose when coughing or sneezing.

- Stay home if you feel unwell.

- Refrain from smoking and other activities that weaken the lungs.

- Practice physical distancing by avoiding unnecessary travel and staying away from large groups of people

Most of the learners belong to modular (print) especially in the rural areas where internet connection is not always available. They are learning with the help of their parents or guardians who are now acting as their teachers at home. The teachers on the other hand, guide the parents while teaching their children at home especially the young ones including the Kindergarten up to Grade 3. The same goes with Grades 4 to 6 but with minimal guidance as compared to those learners in the primary levels who are subject to more attention and supervision. 


\section{HOW DO TEACHERS PERFORM THEIR ROLES IN MODULAR DISTANCE LEARNING?}

Teachers are doing their jobs in this modality by the following:

1) Preparing the Learners' Answer Sheets (LAS) for the learners to write their answers to the weekly tasks in their SLM.

2) Making their Weekly Home Learning Plan (WHLP) which is also given to the learners as guide in their fiveday tasks of learning with the allotted time per day and what subject they are going to learn and study on that particular day.

3) Checking of the retrieved Learners' Answer Sheets (LAS) every week.

4) Giving feedbacks with the scores of the learners in their Learners' Answer Sheets (LAS).

5) Preparing the learners' Intervention Materials for the learners who had a hard time in answering the tasks in Self-Learning Modules (SLM) to make them understand the lesson in the particular subject easily.

6) Monitoring Learner's Performance and reading skills through text messages and phone calls;

7) Answering the parents' questions whenever they have queries about a particular subject and lesson.

\section{WHAT ARE THE TYPES OF ASSESSMENTS USED IN MODULAR DISTANCE LEARNING?}

Assessment as defined by The Glossary of Education Reform, refers to the wide variety of methods or tools that educators use to evaluate, measure, and document the academic readiness, learning progress, skill acquisition, or educational needs of students.

There are different types of assessments used in Philippine education and some of commonly used are the following:

1) Formative Assessment

2) Summative Assessment

3) Performance Assessment

4) Portfolio Assessment

These types of assessment differ from one another.

Formative Assessment are usually not scored or graded as it is being administered every end of the lesson commonly in a five-items multiple choice type of test in order to assess if the learners understand the lesson.

Summative Assessment is used to evaluate learners' understanding and learning in a specific period of time. It can be done weekly as a form of a Quiz, at the end of the unit lessons in a form of a Unit test, and at the end of the Quarter in a form of the Quarterly examination.

Performance Assessment is used to let the learners complete a particular task about the lesson using their skills that will manifest their multiple intelligences. This type of assessment includes: making experiments, singing, making poetry, answering a graphic organizer, making dramatizations and more. It is also called "authentic assessments" since they are considered by some educators to be more accurate and meaningful evaluations of learning achievement than traditional tests. It lets the learners to work collaboratively with their classmates and peers to achieve a common goal based on the tasks. The grading in this type of assessment is done using a performance scoring rubric to evaluate whether the work produced by students shows that they have learned what they were expected to learn.

Portfolio-Based Assessment is a collection of academic works which includes: poems, results of experiments, creative works like drawings, clay sculptures, artworks, handicrafts and writing samples. Portfolio-based assessments are often used to evaluate a "body of knowledge" which is the acquisition of diverse knowledge and skills over a period of time. Portfolio materials are usually collected physically and are often evaluated to determine whether students have met required learning standards.

In this time of the pandemic, face to face classes which have been the norm of education have been cancelled due to the risk of getting infected of Covid-19. That is why; there are different learning modalities being implemented by the Department of Education (DepEd) and the Commission on Higher Education (CHED).

Along this, is the change of assessments being used to measure the learners' knowledge and understanding.

For the Elementary education where Modular (Printed) is implemented, there are two types of assessment used where their grades are generated from and these are summative assessment in a form of quiz or called as "written works" and performance assessment which is called as "performance outputs".

\section{THE CHOSEN PARTICIPANTS OF THE RESEARCH}

The participants of the research were 15 teachers both from the elementary and secondary from Calatagan and nearby towns including, Lian, Tuy and Nasugbu. They were chosen purposively due to lack of face to face interaction due to the covid-19 crisis and those who answered the survey questionnaire has the internet connection at home that made them to be participants possible. They answered a survey questionnaire made out of Google Forms and the link was sent to their emails unlike the usual way of distributing and retrieval of survey questionnaire made out of face to face interaction.

The availability of the internet connection is the primary consideration in choosing the limited participants.

\section{REASONS WHY TEACHERS ARE IN FAVOR OF MODULAR DISTANCE LEARNING?}

- If to consider the engagement capacity of children, modular distance is more convenient.

- It is much accessible for the kind of pupils in the community.

- It can cater pupils who cannot afford gadgets and internet connectivity that will be used in online class.

- This is the appropriate learning modality in our community.

- More time to read/study the lesson.

- It is more reliable and convenient to pupils who do not have gadgets.

- Not every pupil is fortunate like their classmates and most of them only rely on books, that is why modular is more applicable than online learning.

- MDL provides greater flexibility for students to work at their own pace and review work as needed.

- Incapability to access online learning.

\section{REASONS WHY TEACHERS ARE NOT IN FAVOR OF} MODULAR DISTANCE LEARNING?

- Some activity sheets were answered by parents/guardians only

- Pupils have difficulty in answering the modules without the teacher supervision.

\section{WHAT ARE THE ADVANTAGES OF MODULAR DISTANCE LEARNING?}

The pandemic is a year now already and still spreading nonstop in the country. The economy and education are two of the major importance in the country along with the health and welfare of the people. Education should continue and learning should not stop amidst the pandemic. 
Here is the list of advantages of modular distance learning:

\section{LEARNING CONTINUES WHEN THE LEARNERS ADAPT} TO CHANGE

There are more learners who are learning even in this type of academic set-up wherein they are learning at home with the guidance and supervision of their parents in their SLM or their self-learning modules. These learners are openminded learners and flexible with changes in their environment.

\section{PARENTS REALIZE THEIR IMPORTANT ROLE IN THEIR CHILDREN'S EDUCATION}

Due to the covid-19 crisis going on in the country, parents now realized their role in their children's learning and education. They are now aware that teaching is not easy. There are parents who are also adaptive to the present situation and don't blame teachers if these days, they are their children's teachers at home.

\section{MODULAR DISTANCE LEARNING TEACH THE LEARNERS VALUES AS WELL AS THE LESSONS}

The learners are learning not just specific lessons but also the values in this time of pandemic. They learn how to manage their time because even if they are at home, they have to strictly follow their schedule in answering the LAS or the learner's answer sheets based on their SLM or the self-learning modules. They also develop a closer bond with their parents and guardians while having teaching and learning process at home.

\section{TEACHERS BECOME OPEN-MINDED WITH THE CHALLENGES BROUGHT BY THE PANDEMIC}

There are teachers who look at the pandemic as a challenge of educational growth by means of making the (SLMs) selflearning modules, compiling all the necessary lessons and objectives and competencies in a single module for different subjects per quarter.

\section{WHAT ARE THE DISADVANTAGES OF MODULAR DISTANCE LEARNING?}

If there are advantages, there is the opposite of it which is the disadvantages of modular distance learning. Here are some of the disadvantages cited by helpline:

\section{NOT ALL LEARNERS DO THEIR MODULES COMMITTEDLY} Yes, this is $100 \%$ true as per survey. Most students and learners do their modules for formality purposes only and just to simply comply with the requirements. It is very devastating in the part of the teacher to know that students are taking modules for granted. Teachers can only monitor their learners' academic progress through text messaging and phone calls, unlike, the usual face to face classes that they can supervise and facilitate their learning.

\section{SOME PARENTS PAMPER THEIR CHILDREN AND DO THEIR TASK INSTEAD OF THEM}

There are parents who are the ones answering the modules in place of their children for different reasons. There are some who are doing their work from home in an online working set-up, some are busy with the chores and other household tasks that instead of teaching their children with the modules, because they don't have the time to do so, they are the one answering it.

\section{PARENTS ARE HAVING A HARD TIME TEACHING THEIR CHILDREN WITH MODULES}

There are parents who are having a hard time teaching their children at home especially those in the higher grades and the secondary students whom the lessons are more complicated and no one is better to teach than the teacher. There are also parents who do not know how to read and write, making it more difficult to teach their children the lessons in their subject areas.

\section{COMMENTS AND SUGGESTIONS}

Here are some comments and suggestions from the participants:

- Not all the parents/guardians are knowledgeable in teaching their children using the modular distance learning so hard for them.

- MDL should be blended with ODL if possible so the parents and pupils can gain better assistance from teachers.

- Modular distance learning modality is better than online class especially in our locality.

- Maybe they can produce the module earlier so it can help the teachers on doing their WHLP.

- Modular distance helps for continuous educational level of pupils but not actually the learning of them.

\section{RECOMMENDATION}

The following are some recommendation from the participants:

- It would be better if there would be ample time for the quality checking of its content. There should also be areas, particularly in Mathematics, where the lessons should be presented in a more comprehensive manner to be best understood by pupils.

- Adequate learning materials may be provided.

- Parents and teachers should be aware of their roles and responsibilities in teaching learners for them to learn efficiently and effectively.

- Parents should be more patient in helping their children in answering the learning materials as well teachers should also give follow up activities to better understand the lessons.

- Pupils must be responsible to do their modules for continues learning

- Parents should only guide their children in answering the modules. They must not do their task instead.

- Give more concrete examples about the lesson and lessen the activities most especially with the elementary pupils.

\section{GRAPHICAL PRESENTATION OF RESPONSES}

\section{Are you in favor with Modular Distance Learning than online learning?}

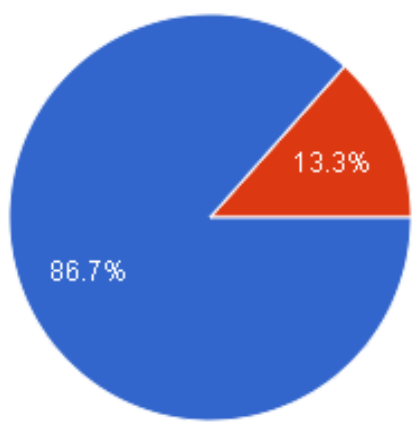

What are the advantages that you have observed in Modular Distance Learning?

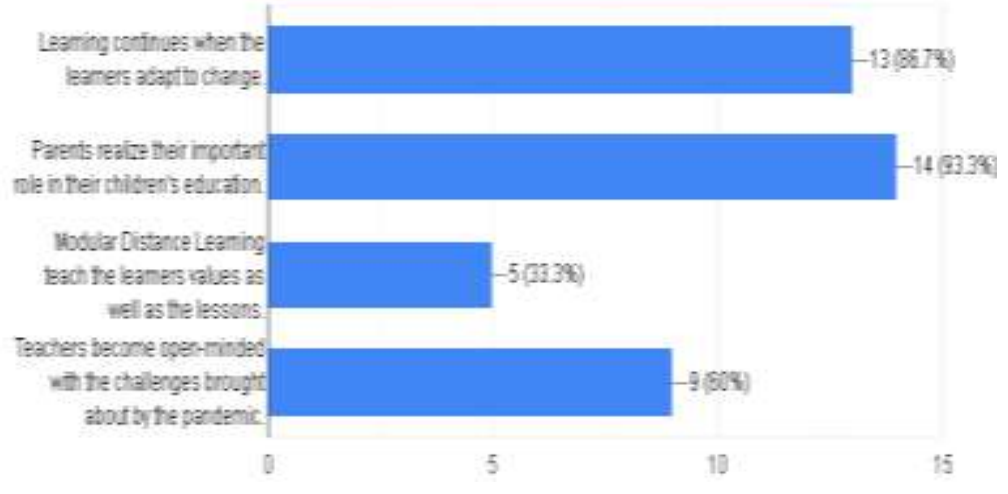


What are the disadvantages that you have observed in Modular Distance Learning?

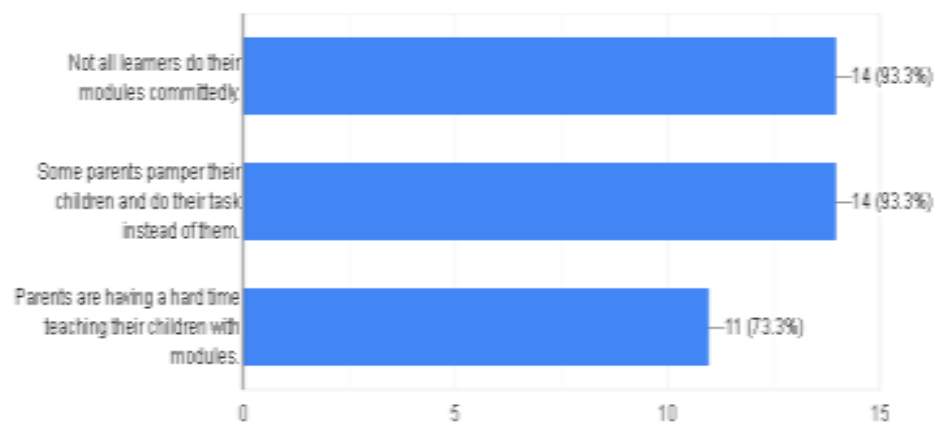

\section{ACKNOWLEDGMENT}

The author wishes to acknowledge Alona M. Mercado the author's thesis adviser in college and Mario A. Cudiamat the author's thesis adviser in MAED for being an inspiration in introduction of research. Also, the author wanted to give thanks to her family for support, her deceased father for being her inspiration in doing great things and her fiancé or soon to be husband who is so supportive and very understanding of less time of communication while making this research.

\section{REFERENCES}

[1] Navarosa, D. \& Fernando, C. (2020). Education in the New Normal: A Closer Look at the Philippines' Learning Solutions Amidst the Pandemic. Retrieved from https://medium.com/underscore-online/education-inthe-new-normal-a-closer-look-at-philippines-learningsolutions-amidst-the-pandemic-ba0adc339d8f

[2] World Health Organization (2020). Coronavirus. Retrieved from https://www.who.int/healthtopics/coronavirus\#tab=tab_1

[3] Malaya, B. (2020). Modular Distance Learning: Here's what you need to know. Retrieved from https://www.whatalife.ph/modular-distance-learningheres-what-you-need-to-know/

[4] Magsombol, B. (2020). FAST FACTS: DepEd's modular learning. Retrieved from

https://www.edglossary.org/assessment/\#: :text=In $\% 20$ education $\% 2 \mathrm{C} \% 20$ the $\% 20$ term $\% 20$ assessment, or $\% 20$ educational $\% 20$ needs $\% 20$ of $\% 20$ students.

[5] Helpline (2020). Advantages and Disadvantages of Modular Learning. Retrieved from https://helplineph.com/opinion/disadvantages-ofmodular-learning/ 